\title{
Perbedaan aliran dalam Islam sebagai konflik hubungan pernikahan dalam perspektif Lewis A. Coser
}

\author{
Grenada Tri Kardiana, Ahmad Arif Widianto* \\ Universitas Negeri Malang, Jl. Semarang No. 5 Malang, Jawa Timur, Indonesia \\ *Penulis korespondensi, Surel: ahmad.arif.fis@um.ac.id
}

Paper received: 01-05-2021; revised: 15-05-2021; accepted: 30-05-2021

\begin{abstract}
The topic of the problem in this research is that there are not a few couples whose relationships are in different schools even though they are in the same Islamic religion. This study aims to analyze what conflicts will occur in a marriage relationship with different streams. So, in this study, the researcher wants to use the conflict theory according to Lewis A. Coser as a knife of analysis. The method used in this research is a qualitative approach, namely the process of exploring and understanding the meaning of individual and group behavior, describing social problems or humanitarian problems. Meanwhile, the type of research used is descriptive qualitative. The sample used was 3 married couples with different sects and 2 unmarried couples, but dating people from different sects. The result of this research is that conflicts can occur between partners, such as forcing them to enter into one of the pairs of streams and it can also occur between families such as damage to the relationship between parents and children.
\end{abstract}

Keywords: differences in flow; marriage; conflict

\begin{abstract}
Abstrak
Topik Permasalahan dalam penelitian ini adalah tak sedikit jumlah pasangan yang menjalin hubungannya berada dalam perbedaan aliran meskipun dalam agama islam yang sama. Penelitian ini bertujuan untuk menganalisis konflik-konflik apa sajakah yang akan terjadi pada hubungan pernikahan berbeda aliran. Sehingga, dalam penelitian ini peneliti ingin menggunakan teori Konflik menurut Lewis A. Coser sebagai pisau analisisnya. Metode yang digunakan dalam penelitian ini adalah Pendekatan Kualitatif yaitu proses eksplorasi dan memahami makna perilaku individu dan kelompok, menggambarkan masalah sosial atau masalah kemanusiaan. Sedangkan, jenis penelitian yang digunakan adalah kualitatif deskriptif. Sampel yang digunakan adalah 3 orang pasangan yang sudah menikah dengan berbeda aliran dan 2 orang yang belum menikah, namun berpacaran dengan orang yang berbeda aliran. Hasil dari penelitian ini adalah konflik bisa terjadi antar pasangan seperti pemaksaan untuk masuk kedalam salah satu aliran pasangan dan juga bisa terjadi antar keluarga seperti rusaknya hubungan antara orang tua dengan anak.
\end{abstract}

Kata kunci: perbedaan aliran; pernikahan; konflik

\section{Pendahuluan}

Agama islam adalah agama mayoritas yang dianut oleh masyarakat Indonesia. Berdasarkan data dari sumber ibtimes.id diperoleh jumlah penganut muslim pada tahun 2020 di Indonesia mencapai 229 juta jiwa. Sedangkan, menurut data nasional.kompas.com yang ditulis oleh Nugraheny (2020) menyebutkan jumlah penduduk Indonesia secara keseluruhan per 30 Juni mencapai 268.583.016 jiwa. Namun, siapa sangka bahwa ternyata agama islam yang menjadi agama mayoritas di Indonesia ini juga memiliki berbagai macam keberagaman dalam hal prinsip, mazhab, ataupun aliran yang dibungkus dengan nama organisasi masyarakat (ormas) islam. Menurut Pamungkas (2015) disebutkan bahwa terdapat dua arus utama dalam islam di Indonesia, yakni Sunni dan Syi'ah. Sunni adalah kelompok umat islam yang mengikuti sunnah dan berjamaah, sehingga disebut ahlussunnah wal jama'ah. 
Ahlusunnah adalah mereka yang senantiasa tegak di atas islam berdasarkan Al qur'an dan hadist yang shahih dengan pemahaman para sahabat tabi'in dan tabi'ut tabi'in. Sementara Syiah adalah kelompok umat islam yang beraliran radikal yang menganggap Ali bin Abi Thalib a.s setingkat atau bahkan lebih tinggi dari Nabi Muhammad SAW (Sahidin, 2015). Organisasi Masyarakat Islam di Indonesia yang paling umum dikenal oleh masyarakat adalah Nahdlatul Ulama (NU) dan Muhammadiyah. Namun, ternyata masih banyak ormas-ormas islam lainnya yang jarang sekali dikenal oleh publik. Menurut Chairunniswah (2013) terdapat 7 organisasi islam yang memiliki peranannya masing-masing, yaitu Jamiat Khair, Al Irsyad, Persyarikatan Ulama, Muhammadiyah, Nahdlatul Ulama, Persatuan Islam (PERSIS), dan Jami'atul Washliyah. Selain itu, berdasarkan sumber dari wikipedia jumlah ormas yang ditemukan semakin banyak, yakni mencapai 33 ormas. Meskipun, sumber ini masih belum jelas kebenarannya bisa kurang atau bisa lebih, sehingga dibutuhkan penelitian yang lebih dalam untuk menemukan jumlah ormas yang sesungguhnya di Indonesia. Namun tetap dijadikan referensi bagi peneliti sebagai informasi tambahan saja. Sementara, data yang disebutkan oleh MUI dalam website resmi CNN Indonesia yang ditulis oleh Rahadian (2016) terdapat 300 lebih aliran sesat yang ada di Indonesia, namun tidak disebutkan secara detail nama-nama aliran atau ormas yang dimaksud.

Berdasarkan data-data diatas memperlihatkan bahwa ternyata fenomena perbedaan prinsip, aliran, ataupun mazhab yang berada di Indonesia memang benar adanya. Hal ini pastinya dapat dipicu oleh beberapa faktor, mengapa sampai terjadi berbagai perbedaan walaupun dalam satu agama, yakni agama islam. Dengan adanya berbagai macam aliran islam yang dianut oleh masyarakat di Indonesia ini, pastinya akan memberikan dampak ataupun efek dalam menjalankan kehidupan yang ada di dunia ini karena pada hakekatnya aliran ataupun ormas yang ada di Indonesia memiliki aturan-aturan atau tujuan yang berbeda-beda satu dengan yang lainnya. Visi Misinya pun juga akan berbeda, dengan demikian proses perjalanan hidup yang dialami oleh masyarakat juga akan berbeda karena akan disesuaikan dengan akidah ataupun aturan yang sesuai dengan aliran masing-masing yang dianutnya. Salah satu perjalanan hidup yang akan dilalui oleh setiap individu adalah sebuah jalinan pernikahan. Pernikahan menurut Sabiq dalam Setiawan (2015) adalah salah satu cara yang dipilih Allah sebagai jalan bagi manusia untuk beranak, berkembang biak, dan melestarikan kehidupannya, setelah masing-masing pasangan siap melakukan peranannya yang positif dalam mewujudkan tujuan pernikahan. Sehingga, dengan adanya berbagai macam aliran, prinsip, atupun mazhab yang ada di Indonesia ini membuat setiap ormas-ormas islam tersebut memiliki akidah pernikahan masing-masing yang disesuaikan dengan sumber kepercayaannya. Beberapa ormas islam memiliki akidah ataupun aturan untuk menjalankan suatu hubungan pernikahan harus dengan pasangan yang satu prinsip, aliran, ataupun mazhab sama. Dalam webiste voaislam.com disebutkan salah satu contoh ormas islam HTI yang menuliskan pendapatnya tentang menikah dengan berbeda ormas apakah sah-sah saja, hal ini beberapa alasan menurutnya mengapa harus ormas adalah organisasi ini memiliki tujuan hidup sebagai pendakwah. Bagi pengemban dakwah menikah merupakan jalan tuk menguatkan keimanan dan gerak dakwahnya serta ada pasangan yang diharapkan mampu membersamainya menjalankan dakwah, Selain itu, dalam Setiawan (2015) juga disebutkan dalam hasil penelitian skripsinya tentang kafaah dalam perkawinan menurut salah satu ormas islam di Indonesia yakni LDII, bahwa dari beberapa wawancara dengan para tokoh jamaah Lembaga Dakwah Islam Indonesia adalah perbedaan konsep kafa'ah dalam hal nasab atau golongan, mereka beranggapan bahwa nasab atau didalam LDII adalah satu golongan dengan mereka, atau satu aliran dengan mereka, yaitu golongan Lembaga Dakwah Islam Indonesia. Contoh lain adalah 
kisah yang diperankan oleh aktris Ayu Shita, Dimas Aditya, dan Ibnu Jamil dalam film berjudul Bid'ah Cinta. Film ini menceritakan kisah percintaan yang dialami oleh Pemuda Muhammadiyah dan Pemudi NU. Meskipun, dalam contohnya ini hanya sebuah film, namun realita yang terjadi pada masyarakat juga sangat banyak.

Dengan demikian, fenomena ini pastinya akan mengakibatkan suatu konflik apabila individu memiliki kisah cinta dengan orang yang tidak sepaham, sealiran, ataupun semahzab. Baik dalam hubungan persiapan pernikahan ataupun pada hubungan rumah tangga itu sendiri. Inilah yang menjadi urgensi dalam penelitian ini, peneliti ingin memahami dan menganalisis lebih dalam mengenai perbedaan prinsip, aliran, ataupun mahzab dalam suatu masyarakat yang bisa saja menjadi penghalang dalam menjalin hubungan pernikahan. Fenomena ini akan dilihat dari perspektif teori konflik. Konflik yang seperti apakah yang akan terjadi apabila masyarakat yang memiliki kisah cinta dengan orang yang tidak satu prinsip, aliran, ataupun mazhab tersebut.

\section{Metode}

Penelitian ini menggunakan pendekatan kualitatif, Pendekatan kualitatif yaitu proses eksplorasi dan memahami makna perilaku individu dan kelompok, menggambarkan masalah sosial atau masalah kemanusiaan. Pengumpulan data bertumpu pada setting partisipan, analisis data secara induktif, membangun data yang parsial ke dalam tema, dan selanjutnya memberikan interpretasi terhadap makna suatu data (Sugiyono, 2013). Metode penelitian yang digunakan adalah penelitian kualitatif deskriptif. Karena dengan menggunakan metode kualitatif deskriptif membantu peneliti untuk mendapatkan data yang lengkap, terperinci, dan lebih mendalam untuk mengkaji fenomena yang terjadi. Dengan adanya Pandemi Covid 19 seperti ini, membuat penelitian tidak bisa dilakukan secara tatap muka. Sehingga, lokasi penelitian dilakukan secara virtual menggunakan aplikasi Whatsapp dengan menggunakan fitur chat dan voice note kepada informan. Waktu Penelitian dilakukan mulai pada bulan Oktober sampai dengan bulan Desember 2020.

Populasi merupakan seluruh kumpulan elemen yang dapat digunakan untuk membuat beberapa kesimpulan (Amirullah, 2015). Populasi dalam penelitian ini adalah seluruh orang penganut aliran tertentu yang memiliki kaidah harus menikah dengan seprinsip, sealiran, ataupun semahzab. Sedangkan, sampel merupakan sebagian dari jumlah dan karakteristik yang dimiliki oleh populasi (Sugiyono, 2011). Sampel yang digunakan dalam penelitian ini adalah 5 orang dengan rincian 3 orang yang menjalin pernikahan dengan pasangan yang berbeda aliran, dan 2 orang yang belum menikah, namun, dalam aliran yang memiliki kaidah atau aturan harus menikah dengan sealirannya. Pengambilan sampel ini menggunakan metode non random sampling. Menurut Hartini (2012) Non random sampling atau non probability sampling merupakan metode pengambilan sampel yang tidak memberi peluang atau kesempatan yang sama bagi setiap anggota populasi untuk dipilih menjadi sampel, karena terdapat beberapa pertimbangan dalam memilih sampel. Jenis sampel yang digunakan oleh peneliti adalah purposive sampling. Purposive sampling merupakan teknik pengambilan sumber data dengan pertimbangan tertentu, misalnya orang yang dianggap paling tahu tentang apa yang kita harapkan atau mungkin dia sebagai penguasa sehingga akan memudahkan peneliti menjelajahi objek atau situasi status sosial yang diteliti (Sugiyono, 2009). 
Pengumpulan data yang digunakan dalam penelitian ini adalah dengan teknik wawancara. Menurut Rahardjo (2011) wawancara ialah proses komunikasi atau interaksi untuk mengumpulkan informasi dengan cara tanya jawab antara peneliti dengan informan atau subjek penelitian. Dengan kemajuan teknologi informasi seperti saat ini, wawancara bisa saja dilakukan tanpa tatap muka, yakni melalui media telekomunikasi. Sesuai dengan kondisi Pandemi Covid 19 ini, membuat peneliti kesulitan dalam melakukan wawancara secara tatap muka, sehingga wawancara akan dilakukan menggunakan aplikasi Whatsapp dengan fitur chat ataupun voice note. Pada hakikatnya, wawancara dilakukan agar mendapat informasi yang mendalam sesuai dengan tema yang dipilih oleh peneliti. Jumlah informan dalam penelitian ini adalah 5 orang, dengan rincian sebagai berikut, Mbak berinisial TRV, Mas GDK, dan Mbak DK yang menikah dengan orang berbeda aliran. Selain itu, peneliti juga ingin melihat perspektif informan yang belum menikah, namun menjalani hubungan dengan pasangan yang berbeda aliran dan diharuskan menikah dengan sekufu/alirannya.. Adapun informan yang belum menikah, yakni Mbak berinisial RD dan mbak HATZ yang belum menikah. Kelima informan ini dipilih dengan berbagai latar ormas islam di Indonesia yang berbeda-beda, serta peneliti juga ingin melihat perspektif dari berbagai keputusan pernikahan yang tidak sealiran. Kemudian, yang akan digali dalam wawancara tersebut adalah fokus pada konflik-konflik seperti apakah yang pernah terjadi ketika sebelum melakukan jalinan pernikahan ataupun saat hubungan pernikahan sudah berlangsung. Setelah data terkumpul, peneliti melakukan validasi data. Validasi data yang peneliti gunakan adalah uji kredibilitas. Uji kredibilitas ini dilakukan dalam tiga tahap, yaitu meningkatkan ketekunan, triangulasi sumber, teknik, waktu (Moleong, 2002).

\section{Hasil dan Pembahasan}

Berdasarkan hasil wawancara dengan 5 Informan tersebut, peneliti berhasil menemukan jawaban atas rumusan masalah yang telah dibuat. Adapun hasil penelitiannya adalah:

\subsection{Penolakan Peraturan Pernikahan yang Harus sekufu atau sealiran}

Menurut mas GDK, sebenarnya beliau beranggapan bahwa hubungan pernikahan harus dalam pemahaman yang sama. Namun, rasa cinta diantara pasangan juga tidak kalah penting. Menurutnya "apabila perbedaan itu masih bisa ditoleransi apalagi masih dalam agama yang sama yakni islam, ya tidak menjadi masalah". Dengan demikian, toleransi dalam hubungan pernikahan yang berbeda aliran menjadi hal yang sangat krusial. Hal ini juga disepakati oleh mbak berinisial HATZ, beliau mengatakan bahwa "pernikahan tidak harus sealiran atau sekufu, tapi kalau bagi saya harus semazhab" hal ini karena baginya mazhab yang ada di Indonesia hanyalah mazhab syafi'i. Seseorang dalam melaksanakan ibadah harus berpedoman pada 1 mazhab. hal ini terjadi karena apabila seseorang mempercayai banyak mazhab, terdapat hal atau cara-cara ibadah yang nantinya akan dipilih paling mudah. Sehingga, baginya perbedaan aliran atau sekufu itu tidak menjadi masalah, asalkan tidak berbeda mazhab karena sudah berhubungan dengan tata cara suatu ibadah. Contoh yang diberikan Mbak HATZ kepada peneliti mengenai seseorang yang mempercayai banyak mazhab adalah, pada mazhab tertentu ada yang mengatakan bahwa seseorang yang telah melaksanakan wudhu tidak papa memegang lawan jenis. Kemudian, untuk tata cara sholat menggunakan mazhab syafi'i. Inilah yang menjadi pertimbangan mbak HATZ dalam memilih pasangan yang harus semazhab. Adapun jawaban dari mbak TRV mengenai pernikahan dalam perbedaan aliran juga tidak masalah. Menurutnya, pernikahan merupakan sesuatu hal yang dilakukan seumur hidup. Dimana, dalam berhubungan ini dibutuhkan rasa nyaman satu sama lain. "Selama ini saya 
mencari-cari pasangan berusaha untuk satu aliran, tapi saya tidak ada yang cocok mbak saya takut apabila dalam menjalani hubungan nanti banyak gak srek nya, terus saya menemukan suami saya ini alhamdulillah nyaman bisa diajak jadi sahabat, partner hidup, suami, teman kerja juga pokoknya semuanya mbak meskipun saya dalam menjalani beberapa ibadah banyak perbedaan." Sehingga, dalam hal ini mbak TRV dalam memilih pasangan hidup mengacu pada rasa nyaman dengan pasangannya. Meskipun, pada realitanya banyak sekali hal-hal yang berbeda dari suaminya seperti, mbak TRV yang dalam alirannya membolehkan tahlilan, sedangkan pada aliran suaminya tidak membolehkan. Namun, suami dari mbak TRV memberikan kelonggaran kepada mbak TRV apabila terdapat saudaranya yang meninggal membolehkan untuk datang dan melaksanakan tahlilan. Inilah yang menjadi kunci dari sebuah hubungan pernikahan, adanya toleransi dan kompromi diantara pasangan suami istri. Perasaan ini juga disepakati oleh mbak berinisial DK, beliau mengatakan bahwa "tidak ada alasan untuk melanjutkan hubungan pernikahan walaupun berbeda aliran, mungkin ya karena udah sayang dan mungkin udah jodohnya amin" berbeda dengan informan sebelumnya, karena pada akhirnya mbak DK memutuskan untuk mengikuti aliran yang dipercayai oleh suami.

\subsection{Konflik yang terjadi pada Pernikahan Berbeda Aliran}

Berdasarkan hasil wawancara yang telah dilakukan, konflik yang terjadi sebagian besar adalah sama,yakni terjadi pada hubungan antar keluarga. Menurut mas GDK, konflik keras yang terjadi adalah pada saat sebelum pernikahan atau saat pacaran. Dalam alirannya, pacaran adalah hal yang sangat tidak dibolehkan, orang tua dari mas GDK sangat paham akan hal itu, namun beberapa upaya telah dilakukan mas GDK untuk menunjukkan ke orang tua bahwa pasangan yang dipilihnya adalah yang terbaik. Bahkan, kalimat-kalimat kasar yang dikeluarkan dari mulut orang tuanya juga sering dilontarkan. Kalimat-kalimat itu seperti "Uripmu gak bakal barokah lek rabi ambek wong jobo" kalimat ini mengandung arti hidup dari mas GDK tidak akan berkah apabila menikah dengan orang yang tidak sealiran dengannya. Selain itu, beberapa kali mas GDK juga sering membuat ibunya menangis karena keputusannya yang tidak mau putus dengan istrinya dahulu kala sampai pada akhirnya menikah seperti ini. Hal ini juga dirasakan oleh mbak DK, beliau mengatakan terdapat konflik antara dirinya dengan keluarga karena dikhawatirkan mbak DK akan mengikuti aliran-aliran yang sesat seperti suaminya. Sementara pada mbak TRV, konflik tidak hanya pada antar keluarga saja, melainkan juga pernah terjadi di hubungan pasangannya masing-masing "pernah mbak, dulu itu saya debat sama suami saya tentang kebenaran dari aliran masing-masing kita ini. nguotot kalau ajaran saya ini benar sampai-sampai pernah tidak berkomunikasi selama beberapa minggu" ujarnya. Namun, hubungan itu kembali lagi karena kedua belah pihak merasa masih saling menyayangi dan cocok. Sehingga, mereka menyadari bahwa ketika akan menikah nantinya harus siap dengan segala resiko yang ada. Adapun untuk informan berinisial HATZ dan RD ini masih belum menikah, namun konflik sudah sering terjadi di antara satu sama lain pasangan. Mbak HATZ pernah memaksakan pacarnya untuk masuk di alirannya demi hubungan itu tetap berlanjut. Pihak keluarga dari mbak HATZ juga sudah mengetahui akan hubungan tersebut karena sudah berjalan 3,5 tahun. Namun, ajakan dari mbak HATZ untuk menyuruh pacarnya masuk dalam alirannya ditolak mentah-mentah. Menurut pacarnya, saat ini belum waktu yang tepat untuk pacarnya mengikuti kajian-kajian di aliran mbak HATZ. Padahal, menurut mbak HATZ melihat pacarnya yang masih bisa dibilang tidak mengikuti aliran manapun menjadi kesempatan untuknya memperkenalkan tentang aliran yang diikuti. Sehingga, penolakan yang diberikan oleh pacar mbak HATZ ini berkaitan erat dengan soal 
"hidayah". Beberapa kali, pacar mbak HATZ datang kerumah untuk menemuinya. Namun, konflik terjadi antara keluarga dengan pacar mbak HATZ sampai diusir dari rumah mbak HATZ. Walaupun segala konflik terjadi baik antar pasangan maupun antar keluarga, hubungan ini masih berlanjut sampai detik ini. Bahkan, mereka juga sudah merencanakan ke jenjang yang lebih serius yakni pernikahan. Sedangkan, konflik yang terjadi pada mbak RD masih batas wajar karena hubungannya masih 2 tahun dan belum ada pembahasan yang lebih serius ke jenjang pernikahan. Hal ini juga dipengaruhi oleh faktor mbak RD yang masih duduk di bangku perkuliahan. Sehingga, orang tua dari mbak RD masih menganggap hubungan anaknya dengan pacarnya hanya sebatas cinta monyet. Bentuk konflik yang dirasakan mbak RD dari orang tua adalah tidak diperbolehkannya keluar berdua dan hanya menjalin hubungan melalui chat whatsapp saja. Dari hasil kelima informan tersebut memberikan gambaran kepada peneliti bahwa konflik apapun yang terjadi pada pernikahan berbeda aliran ini tidak membuat hubungan percintaan kandas begitu saja.

Penelitian ini menggunakan teori konfik Lewis A. Coser karena dianggap relevan dalam menganalisis fenomena yang dipilih. Dengan adanya perbedaan prinsip ataupun aliran ini pastinya akan berpengaruh terhadap akidah atau aturan yang dijalankan oleh setiap orang. Teori Lewis A. Coser ini dikembangkan dari teori-teori yang telah dibuat oleh George Simmel. Berbeda dengan beberapa ahli sosiologi yang menegaskan eksistensi dua perspektif yang berbeda (teori fungsionalis dan teori konflik), Coser mengungkapkan komitmennya pada kemungkinan menyatukan kedua pendekatan tersebut (Albar, 2020). Teori Konflik Coser ini juga disebut dengan konflik realistis-non realistis dan katup penyelamat. Menurut Poloma dalam (Nugroho et al., 2017) Konflik realistis merupakan konflik secara langsung yang muncul karena adanya rasa kecewa terhadap paksaan yang terdapat dalam sebuah hubungan. Apabila dikaitkan dengan penelitian ini adalah dapat dibuktikan dengan konflik yang bisa terjadi karena adanya paksaan dari orang tua untuk menikahkan anaknya dengan sealiran. Bahkan, konflik juga terjadi antar pasangan karena satu sama lain yang ingin memasukkan pasangan kepada alirannya masing-masing yang dianggap paling benar. Sedangkan, konflik non-realistis, yakni konflik yang secara tidak langsung terjadi dalam diri, tetapi dipengaruhi dari luar atau pihak ketiga. Dalam hal ini dapat dicontohkan apabila pasangan yang memaksakan pasangannya untuk masuk ke aliran yang dianutnya, namun tidak dasar keyakinan hatinya, melainkan faktor eksternal atau sistem pada alirannya sendiri itulah yang membuat pasangan harus seperti itu. Pada dasarnya konflik juga dapat diredakan melalui katup penyelamat (safety-valve). Katup penyelamat merupakan cara untuk meredakan suatu masalah atau konflik yang terjadi antar individu atau kelompok (Arisandi, 2015). Sehingga, menurutnya Konflik merupakan kesadaran seseorang untuk melakukan pembaharuan menjadi yang lebih baik atas masalah yang terjadi. Dalam penelitian ini, teori yang ingin digunakan adalah pada katup penyelamat (safety-valve) yakni salah satu mekanisme khusus yang dapat dipakai untuk mempertahankan kelompok dari kemungkinan konflik sosial dengan membiarkan luapan permusuhan tanpa menghancurkan seluruh struktur, membantu membersihkan konflik dalam kelompok yang sedang kacau. Hal ini dapat dibuktikan dengan adanya konflik-konflik yang terjadi baik antar keluarga maupun antar pasangan mendatangkan hal positif setelahnya. Setelah mengalami perdebatan antar pasangan, bahkan sempat tidak berhubungan selama berminggu-minggu namun hal ini akan menjadi fase istirahat dan intropeksi. Bahwa, pada kenyataannya satu sama lain masih menyayangi. Bahkan, setelahnya hubungan itu akan menjadi kuat. Kalimat Lewis A.Coser tentang "Konflik merupakan kesadaran seseorang untuk melakukan pembaharuan menjadi yang lebih baik atas masalah yang terjadi” dapat dibuktikan 
dengan penjelasan mas GDK bahwa, dengan adanya konflik dirinya dengan ibu kandungnya, terdapat proses pembenahan diri kepada pasangannya untuk menunjukkan kepada ibunya bahwa pilihannya adalah yang terbaik. Disini, terdapat pembaharuan hubungan antara ibu dan anak setelah adanya konflik. Apalagi, saat mas GDK dan istri sudah memiliki anak, hubungan itu akan menjadi lebih baik. Fungsi positif dari konflik menurut Lewis A. Coser merupakan cara atau alat untuk mempertahankan, mempersatukan, dan bahkan untuk mempertegas sistem sosial yang ada. Hal ini sesuai dengan fokus penelitian ini, hasil dari penelitian ini adalah dengan adanya konflik yang terjadi pada pasangan yang berbeda aliran terdapat berbagai cara dan upaya yang telah dilakukan masing-masing pasangan untuk mempertahankan hubungannya. Berdasarkan Proposisi yang dikemukakan oleh Lewis A. Coser hal-hal ini selaras dengan hasil penelitian yaitu: 1) Kekuatan solidaritas internal dan integrasi kelompok yang timbul saat konflik berlangsung. Dalam hal ini, sesuai dengan penjelasan informan, bahwa dengan adanya konflik membuat masing-masing pasangan sadar bahwa setelah terjadinya konflik akan ada rasa "saling membutuhkan", "saling sayang" dan patut untuk dipertahankan. Meskipun, pada mulanya konflik terjadi, namun saat sudah merasakan tidak enaknya kehilangan akan menjadi alasan besar dalam mempertahankan hubungan tersebut. Selain itu, apabila konflik terjadi pada orang tua kepada anak dan pasangannya, ini akan membuat hubungan yang lebih kuat antara pasangan. Hal ini terjadi apabila keduanya memiliki kekuatan cinta yang luar biasa. Namun, juga dapat goyah apabila tidak didasari kekuatan yang baik diantara keduanya. 2) Integritas yang semakin tinggi dari kelompok yang terlibat dalam konflik dapat membantu memperkuat batas antar kelompok itu dan kelompok-kelompok lainnya dalam lingkungan itu, khususnya kelompok yang bermusuhan atau secara potensial dapat menimbulkan permusuhan. Dalam indikator ini dapat dicontohkan dari pihak orang tua atau keluarga besar untuk menjelaskan kepada anaknya bahwa aliran yang dipercayainya benar dan harus mengikuti aturan aliran yang ada. Disini, terdapat kekompakan antara orang tua. Bahkan, perlakuan keluarga yang dicontohkan oleh mbak HATZ sampai mengusir pacarnya dari rumah adalah bentuk integrasi keluarga atas penolakan kepada pacar mbak HATZ. 3) Semakin tingginya tekanan pada consensus dan konformitas. Dalam hal ini dapat dicontohkan dengan adanya kesepakatan yang dilakukan oleh masing-masing pasangan dalam melanjutkan hubungannya, meskipun segala resiko besar akan datang. Seperti yang terjadi pada mbak DK dan pasangannya, bahwa pada akhirnya terjadi kompromi di diri mbak DK, beliau sedikit demi sedikit penasaran dengan aliran yang dipercayai oleh suaminya, ia ingin membuktikan apakah yang dikatakan ibunya mengenai aliran suaminya adalah sesat itu benar atau tidak. Walaupun pada mulanya penuh dengan konflik, namun keputusan mbak DK untuk masuk ke aliran suaminya tidak membuat hubungannya dengan ibunya semakin jauh, mbak DK membuktikan bahwa dengan mengikuti aliran suaminya ia menjadi pribadi yang lebih baik dan paham akan agama islam. Sikap kepada orang tuanya juga semakin tawadhu, sehingga membuat konflik yang terjadi keduanya hilang begitu saja dan menghasilkan keadaan baru yang lebih baik.

Karena pada dasarnya, konflik akan terjadi pada siapa saja, dimana saja, dan kapan saja terlepas dari hubungan pernikahan beda aliran atau tidak. Setiap keluarga pastinya akan selalu ada yang namanya konflik, apalagi dalam fenomena yang dipilih oleh peneliti adalah perbedaan agama yang menjadi penghalang dalam jalinan hubungan pernikahan. Fenomena tersebut pastinya sangat rentan dengan konflik, baik secara internal maupun eksternal. Sehingga, sesuai dengan penjelasan diatas bahwa teori konflik Coser ini cocok dalam menganalisis fenomena ini, dimana perluasan masalah dilakukan tidak untuk merusak, namun sebagai pengintegrasian hubungan keluarga menjadi lebih baik. 


\section{Simpulan}

Adapun kesimpulan dari penelitian ini adalah konflik yang terjadi pada hubungan pernikahan beda aliran bisa terjadi baik antar pasangan maupun antar keluarga. Konflik antar pasangan dapat dicontohkan dengan adanya perdebatan bahwa alirannya yang paling benar, sehingga terdapat paksaan untuk masuk ke aliran salah satu pasangan. Selain itu, adanya kerenggangan dalam hubungan juga akan terjadi kepada pasangan pada saat awal beradaptasi dan proses pengenalan. Sedangkan, konflik yang terjadi antar keluarga adalah adanya rusaknya hubungan antara anak dengan orang tua, seperti kalimat-kalimat kasar yang dikeluarkan dari mulut seorang ibu hingga pada pengusiran pasangan anak dari rumah. Berdasarkan hasil penelitian, konflik-konflik yang terjadi lebih banyak terjadi saat sebelum memutuskan pernikahan atau saat pacaran. Hal ini disebabkan karena satu sama lain masih dalam proses pengenalan dan masih mengutamakan ego masing-masing. Hal-hal yang dibutuhkan dalam sebuah hubungan pernikahan tidak hanya didasari oleh persamaan aliran saja, melainkan juga pada perasaan nyaman dan cinta antar pasangan. Sehingga, apabila kedua belah pihak memutuskan untuk menjalin hubungan pernikahan dalam berbeda aliran harus dipenuhi dengan rasa toleransi dan kompromi yang luar biasa. Pernikahan yang didasari oleh satu aliran saja sudah akan menimbulkan berbagai konflik, apalagi dengan pasangan yang berada di dalam perbedaan aliran. Hal ini sesuai dengan pendapat Lewis A.Coser bahwa konflik yang terjadi tidak harus merusakkan atau bersifat disfungsional bagi sistem yang bersangkutan karena konflik bisa juga menimbulkan suatu konsekuensi yang bersifat positif. Seperti contoh yang ada pada hasil penelitian bahwa banyak sekali konflik yang terjadi pada pasangan, bahkan hampir memutuskan untuk berhenti menjalin hubungan tersebut. Namun dengan adanya konflik tersebut, konflik berhasil diselesaikan dan bahkan menyadarkan kedua belah pihak bahwa mereka tidak bisa dipisahkan atau berhenti begitu saja karena sudah terlanjur mencintai. Sesuai dengan proposisi Lewis A. Coser bahwa dengan adanya konflik akan terjadi Kekuatan solidaritas internal dan integrasi kelompok, Memperkuat batas antar kelompok itu dengan kelompok-kelompok lainnya, serta Semakin tingginya tekanan pada consensus dan konformitas.

\section{Daftar Rujukan}

Albar, Q. (2015). Akomodasi Perkawinan Beda Agama Pada Lansia di Surabaya: Studi Tentang Strategi Mengakomodasi Konflik Spiritual (Doctoral dissertation, UNIVERSITAS AIRLANGGA).

Amirullah, S.E (2015). Populasi dan sampel (pemahaman, jenis dan teknik). file://C:/Users/HP/Downloads/POPULASI\%20DAN\%20SAMPEL.pdf diakses pada tanggal 21 Oktober 2020 pada pukul 12:18

Arisandi, H. (2015). Buku Pintar Pemikiran Tokoh-Tokoh Sosiologi Dari Klasik Sampai Modern. Yogyakarta: IRCiSoD.

Chairunniswah, C. (2013). Organisasi Islam dan Peranannya Bagi Pendidikan Islam di Indonesia. diakses dari file:///C:/Users/HP/Downloads/39-Article\%20Text-76-1-10-20150505.pdf pada tanggal 21 Okober 2020 pukul 09:54

Hartini, S. (2012). Perilaku pembelian smartphone: analisis brand equity dan brand attachment. Jurnal Mitra Ekonomi dan Manajemen Bisnis, 3(1), 75-86.

Pamungkas.G.K. (2015). Realita Kelompok-Kelompok Islam di Indonesia. diakses dari https://www.kompasiana.com/gilangkurniapamungkas/5560421fb57a618d0156ae50/realitakelompokkelompok-islam-di-indonesia pada tanggal 21 Oktober 2020 pukul 09:36

Moleong, Lexy J. (2002). Metodologi Penelitian Kualitatif. Bandung: PT Remaja Rosdakarya.

Nugraheny, D. E. (2020). Data Kependudukan 2020: Penduduk Indonesia 268.583. 016 Jiwa.

Selarani, K., Punia, I. N., \& Nugroho, W. B. (2018). Fenomena Pacaran Berbeda Agama di Kalangan PemudaPemudi Kota Denpasar. 
Jurnal Integrasi dan Harmoni Inovatif Ilmu-Ilmu Sosial, 1(5), 2021, 582-590

Rahadian, L. (2016). MUI: Ada 300 lebih aliran sesat di Indonesia. diakses dari https://www.cnnindonesia.com/nasional/20160121180616-12-105893/mui-ada-300-lebih-aliransesat-di-indonesia pada tanggal 21 Oktober 2020

Rahardjo, M. (2011). Metode pengumpulan data penelitian kualitatif.

Sahidin, A. (2015). Memahami Sunni dan Syiah: Sejarah, Politik, dan Ikhtilaf. dalam Jurnal Maarif, 10, 31-51.

Setiawan, W. (2015). Kafa'ah dalam perkawinan menurut Jama'ah Lembaga Dakwah Islam Indonesia di Desa Mojolawaran Kecamatan Gabus Kabupaten Pati (Doctoral dissertation, UIN Walisongo).

Sugiyono, S. (2009). Metode Penelitian Kuantitatif, Kulitatif, dan R\&D. Bandung: Afabeta.

Sugiyono, P. D. (2015). Cara Mudah Menyusun: Skripsi, Tesis, dan Disertasi. Bandung: Alfabeta. 